\title{
Employing FAD-Dependent Glucose Dehydrogenase within a Glucose/Oxygen Enzymatic Fuel Cell Operating in Human Serum
}

\author{
Ross D. Milton ${ }^{\mathrm{a}}$, Koun Lim ${ }^{\mathrm{a}}$, David P. Hickey a and Shelley D. Minteer, ${ }^{\mathrm{a},{ }^{\mathrm{a}}}$ \\ ${ }^{a}$ Department of Chemistry and Materials Science and Engineering, University of Utah, $315 \mathrm{~S}$ \\ 1400 E Room 2020, Salt Lake City, UT 84112 \\ "Corresponding Author: Phone: (801)587-8325, Email: minteer@chem.utah.edu
}

\begin{abstract}
Flavin adenine dinucleotide-dependent glucose dehydrogenase (FAD-GDH) is emerging as an oxygen-insensitive alternative to glucose oxidase (GOx) as the biocatalyst for bioelectrodes and bioanodes in glucose sensing and glucose enzymatic fuel cells (EFCs). Glucose EFCs, which utilize oxygen as the oxidant and final electron acceptor, have the added benefit of being able to be implanted within living hosts. These can then produce electrical energy from physiological glucose concentrations and power internal or external devices. EFCs were prepared with FADGDH and bilirubin oxidase (BOx) to evaluate the suitability of FAD-GDH within an implantable setting. Maximum current and power densities of $186.6 \pm 7.1 \mu \mathrm{A} \mathrm{cm}^{-2}$ and $39.5 \pm 1.3 \mu \mathrm{W} \mathrm{cm}$ were observed when operating in human serum at $21^{\circ} \mathrm{C}$, which increased to $285.7 \pm 31.3 \mu \mathrm{A} \mathrm{cm}^{-}$ 2 and $57.5 \pm 5.4 \mu \mathrm{W} \mathrm{cm}{ }^{-2}$ at $37^{\circ} \mathrm{C}$. Although good stability was observed with continual nearoptimal operation of the EFCs in human serum at $21^{\circ} \mathrm{C}$ for 24 hours, device failure was observed between 13-14 hours when continually operated at $37^{\circ} \mathrm{C}$.
\end{abstract}

Keywords: FAD-dependent glucose dehydrogenase, bilirubin oxidase, serum, glucose, oxygen

\section{Introduction}

Enzymatic fuel cells (EFCs) are devices that incorporate enzymes as biocatalysts at both the anode and cathode of a fuel cell, which further provides the possibility for devices to generate electrical energy from common alternative fuels (such as glucose, fructose, sucrose and ethanol) in the presence of oxygen, under relatively mild conditions. ${ }^{1-8}$ Since EFCs can operate on fuels present within physiological fluid (glucose), there is an ever-increasing drive to design EFCs that can produce electrical energy following implantation into a living host. The implantation of EFCs has been demonstrated within living hosts such as snails, cockroaches, clams and rats, where the bioanodes typically incorporate either glucose oxidase (GOx) or pyrroloquinoline quinone-dependent glucose dehydrogenase (PQQ-GDH) ${ }^{9-13}$ In the future (once significant stability-related issues associated with theses EFCs are overcome), glucose-fueled devices could be implanted within the human body to power health-management devices, such as insulin monitoring/regulation systems and pacemakers. The operation and application of several EFCs in human serum has been previously demonstrated. ${ }^{14-17}$

The use of enzymatic biocatalysts (which are often cheaper than their counterpart precious metal catalysts) can result in improved fuel cell design and performances, since substrate specificity of enzymes allows for operation within single-compartment membrane-less 
configurations. ${ }^{18,19}$ Substrate specificity is especially useful when considering the implantation of EFCs into living hosts, since it is possible that other compounds present within the physiological fluid of choice (such as paracetamol/acetaminophen, ascorbic acid and urea) could have adverse or competing affects on enzymes.

The authors have recently demonstrated that the choice of anodic and cathodic enzymes should be carefully considered, since the commonly used and commercially available anodic enzyme GOx (E.C. 1.1.3.4) can significantly affect oxygen-reducing enzymatic cathodes. ${ }^{20,} 21$ Due to undesired side-reactions associated with GOx and the resulting loss of coulombic efficiency (due to the biocatalytic reduction of $\mathrm{O}_{2}$ to $\mathrm{H}_{2} \mathrm{O}_{2}$ ), alternative glucose-oxidizing enzymes are commonly replacing GOx. One such enzyme, which is rapidly emerging in EFC technologies, is flavin adenine dinucleotide-dependent GDH (FAD-GDH, E.C. 1.1.99.10). Although the crystal structure of fungal FAD-GDH has not yet been resolved, it is reported to be monomeric with an approximate molecular weight of $88-135 \mathrm{kDa} \cdot{ }^{22-24}$ The main advantage of the use of FAD-GDH over GOx is its inherent oxygen-insensitivity, whereby FAD-GDH does not utilize oxygen as its natural electron acceptor. ${ }^{24}$ Its use in the place of GOx therefore alleviates the production of $\mathrm{H}_{2} \mathrm{O}_{2}$ at the anode of EFCs which have been shown to affect common oxygen-reducing enzymes utilized at biocathodes; although biological systems are in place to rapidly decompose $\mathrm{H}_{2} \mathrm{O}_{2}$ in a physiological setting (catalase), the exclusion of $\mathrm{H}_{2} \mathrm{O}_{2}$ production is preferred and increases the simplicity of EFC design where further countermeasures need not be included. ${ }^{20,} 21,25$ Furthermore, the reduction of oxygen by GOx results in the rapid deletion of dissolved oxygen, which is significant in single-compartment EFCs because oxygen is the final electron acceptor required at the biocathode.

Although alternative glucose-oxidising enzymes such as PQQ-GDH (E.C. 1.1.5.2) and nicotinamide adenine dinucleotide-dependent GDH (NAD-GDH, E.C. 1.1.1.118) exhibit oxygen-insensitivity, it could be considered favorable to maintain the use of FAD-dependent enzymes at the bioanode of EFCs, since the relatively-lower redox potential of the FAD cofactor enables the use of electron mediators across a wider potential window. This can result in larger open-circuit voltages (OCVs) and thus, larger overall power densities of devices because a larger potential difference between the onset of bioelectrocatalysis at the bioanode and biocathode can be introduced. ${ }^{1}$ Several recent studies have investigated and reported the use of FAD-GDH for both biosensors and EFCs, showing great promise as a potential commercially-available replacement for GOx..$^{20-24,26}$

In terms of enzymatic oxygen-reducing cathodic enzymes, laccase (E.C. 1.10.3.2) and bilirubin oxidase (BOx, E.C. 1.3.3.5) are the two most-commonly utilized biocatalysts in EFCs; both of these enzymes are classed as multi-copper oxidases (MCOs) due to their type 1 (T1), type 2 (T2) and type 3 (T3) catalytic copper centers, where 1xT2 and 2xT3 Cu centers make up a trinuclear cluster (TNC). In the cases of laccase (Trametes sp.) and BOx (Myrothecium sp.), substrates typically undergo single-electron oxidation at the T1 site. Following substrate oxidation, 4 electrons are then individually transported (via a His-Cys-His tripeptide chain) to the TNC of the MCOs, where oxygen then undergoes a 4-electron reduction to $\mathrm{H}_{2} \mathrm{O}$. 
For in vivo, studies the use of $\mathrm{BOx}$ is preferred since it typically offers increased resilience to halide anion inhibition over laccase and is more suited to applications in nearneutral $\mathrm{pH}$; although laccase can operate in near-neutral $\mathrm{pH}$, the relatively high potential of the $\mathrm{T} 1 \mathrm{Cu}$ center for laccase with optimal performances in acidic conditions is typically inverselyproportional to higher $\mathrm{pH}$ values. ${ }^{25,}{ }^{27-34}$ In contrast, BOx can operate at near-neutral $\mathrm{pH}$ whilst retaining a relatively high $\mathrm{T} 1$ redox potential, which is important for increasing OCVs of EFCs since the redox potential of the $\mathrm{T} 1$ site lies close to the onset potential of direct bioelectrocatalytic oxygen reduction. ${ }^{33-35}$ Orientational docking of MCOs via their $\mathrm{T} 1 \mathrm{Cu}$ site (first demonstrated by Armstrong and co-researchers) is also commonly employed, since DET characteristics can be improved and further resilience to $\mathrm{Cl}^{-}$inhibition can be instilled. ${ }^{25}, 32,36-38$

In this study, the characteristics of a FAD-GDH bioanode and a BOx biocathode as well as the resulting complete EFC were evaluated, operating in human serum. Ferrocene $(\mathrm{Fc})$ and derivatives, including dimethylferrocene $\left(\mathrm{FcMe}_{2}\right)$, was first reported by Turner and co-workers to mediate the bioelectrocatalytic oxidation of glucose by GOx. ${ }^{39}$ At the bioanode, a previouslyreported linear polyethyleneimine (LPEI) polymer was grafted with $\mathrm{FcMe}_{2}$ (separated by a propyl linker, $\mathrm{FcMe}_{2}-\mathrm{C}_{3}$-LPEI) and was utilized as a redox hydrogel for the mediated bioelectrocatalytic oxidation of glucose via FAD-GDH (Equations 1-3). ${ }^{40}$

$$
\begin{gathered}
\mathrm{GDH}(\mathrm{FAD})+\text { glucose } \rightarrow \mathrm{GDH}\left(\mathrm{FADH}_{2}\right)+\text { gluconolactone } \\
\mathrm{GDH}\left(\mathrm{FADH}_{2}\right)+2 \mathrm{FcMe}_{2}^{+} \rightarrow \mathrm{GDH}(\mathrm{FAD})+2 \mathrm{FcMe}_{2} \\
2 \mathrm{FcMe}_{2} \leftrightarrow 2 \mathrm{FcMe}_{2}^{+}+2 \mathrm{e}^{-}
\end{gathered}
$$

At the biocathode BOx was immobilized onto multi-walled carbon nanotubes, which were modified with anthracene moieties (AcMWCNTs), to act as orientational docking aids whilst improving DET and direct bioelectrocatalysis characteristics. ${ }^{21,25}$

\section{Experimental}

\subsection{Chemicals and Materials}

Sodium phosphate (dibasic), citric acid, tetrabutylammonium bromide (TBAB), Nafion ${ }^{\circledR}$ perfluorinated resin, dimethylferrocene $\left(\mathrm{FcMe}_{2}\right)$, bromopropanoyl chloride, aluminum chloride, sodium bicarbonate, sodium chloride, sodium hydroxide, magnesium sulfate, borane-tertbutylamine, poly(2-ethyloxazoline), dichlorophenolindophenol, D-glucose, human serum (from whole blood, male type AB), albumin from bovine serum (BSA), 2,2'-azino-bis(3ethylbenzothiazoline-6-sulphonic acid) (ABTS) and paraffin wax were purchased from SigmaAldrich (St. Louis, MO) and used as received, unless specified otherwise. Flavin adenine dinucleotide-dependent glucose dehydrogenase (FAD-GDH, E.C. 1.1.99.10, GLDE-70-1192, Aspergillus sp.) was purchased from Sekisui Diagnostics (Lexington, MA, USA) and used as received. Bilirubin oxidase (BOx, E.C. 1.3.3.5, Myrothecium sp., BO-3) was obtained from Amano Enzyme Inc. (Japan) and used as received. Hydroxyl-modified multi-walled carbon 
nanotubes (MWCNTs-OH) were purchased from www.cheaptubes.com. Glassy carbon (GC) electrodes (3 mm diameter) were purchased from $\mathrm{CH}$ Instruments, Inc. (TX, USA). Untreated Toray ${ }^{\circledR}$ paper was purchased from Fuel Cell Earth (TPG-H-060) and used as received. Ethylene glycol diglycidyl ether (EGDGE) was purchased from Polysciences, Inc. and used as received. Water used was taken from a Millipore Type 1 (Ultrapure) Milli-Q system $(18.2 \mathrm{M} \Omega \mathrm{cm}$ ). Glucose solutions were allowed to mutarotate for 24 hours and were kept refrigerated at $4{ }^{\circ} \mathrm{C}$ until use. The specific enzymatic activity of BOx was determined to be $5.45 \pm 0.03 \mathrm{U} / \mathrm{mg}\left(21^{\circ} \mathrm{C}\right)$ and $5.18 \pm 0.21\left(37^{\circ} \mathrm{C}\right)$ using $\mathrm{ABTS}$ as the redox indicator at $\mathrm{pH} 7.4$. The specific enzymatic activity of FAD-GDH was determined to be $183.3 \pm 24.9\left(21^{\circ} \mathrm{C}\right)$ and $221.4 \pm 30.0\left(37^{\circ} \mathrm{C}\right)$ using a dichlorophenolindophenol (DCPIP) assay at $\mathrm{pH}$ 7.4. The molar absorptivity of DCPIP was determined to be $15.3 \mathrm{mM}^{-1} \mathrm{~cm}^{-1}$ at $\mathrm{pH}$ 7.4.

Linear polyethyleneimine modified with dimethylferrocene and separated by a 3-carbon spacer $\left(\mathrm{FcMe}_{2}-\mathrm{C}_{3}\right.$-LPEI) was synthesized by a modified previously published procedure. ${ }^{40}$ Initially, 3-(dimethylferrocene)-propanoyl bromide was synthesized by the following procedure. 3-bromopropanoyl chloride $(0.48 \mathrm{~g}, 2.8 \mathrm{mmol})$ was added to a suspension of aluminum chloride $(0.37 \mathrm{~g}, 2.8 \mathrm{mmol})$ in $\mathrm{CH}_{2} \mathrm{Cl}_{2}(20 \mathrm{~mL})$ at $0^{\circ} \mathrm{C}$ and stirred for 1 hour. The mixture was added slowly to a stirring solution of dimethylferrocene $(0.50 \mathrm{~g}, 2.3 \mathrm{mmol})$ in $\mathrm{CH}_{2} \mathrm{Cl}_{2}(50 \mathrm{~mL})$ at $0^{\circ} \mathrm{C}$. The resulting purple solution was stirred for 18 hours at room temperature. This solution was diluted with $\mathrm{CH}_{2} \mathrm{Cl}_{2}(20 \mathrm{~mL})$ and poured over an equivalent volume of ice. The product was extracted with $\mathrm{CH}_{2} \mathrm{Cl}_{2}$ and the organic phase was washed with a saturated aqueous solution of $\mathrm{NaHCO}_{3}$ and brine. The organic portion was filtered over $\mathrm{MgSO}_{4}$ and concentrated under reduced pressure. $0.93 \mathrm{~g}$ of crude product mixture was obtained. No further analysis was performed prior to the next step in the reaction sequence.

Next, 3-(dimethylferrocene)-propanoyl bromide was reduced to 3(bromopropyl)dimethylferrocene. Borane-tert-butylamine complex $(0.61 \mathrm{~g}, 7.0 \mathrm{mmol})$ in $\mathrm{CH}_{2} \mathrm{Cl}_{2}$ $(10 \mathrm{~mL})$ was added to a suspension of aluminum chloride $(0.47 \mathrm{~g}, 3.5 \mathrm{mmol})$ in $\mathrm{CH}_{2} \mathrm{Cl}_{2}(20 \mathrm{~mL})$ at $0^{\circ} \mathrm{C}$. After the mixture was stirred for 1 hour, the 3-(dimethylferrocene)propanoyl bromide product from the previous reaction $(0.82 \mathrm{~g}, 2.3 \mathrm{mmol})$ in $\mathrm{CH}_{2} \mathrm{Cl}_{2}(10 \mathrm{~mL})$ was added slowly over 15 minutes. The resulting solution was stirred for 18 hours at room temperature under a slow stream of nitrogen gas. The reaction mixture was hydrolyzed with water and extracted with $\mathrm{CH}_{2} \mathrm{Cl}_{2}$. The crude product was purified by flash chromatography (silica gel; $\mathrm{CH}_{2} \mathrm{Cl}_{2}$ ) to afford a yield of $48 \%$ (0.43 g, $1.2 \mathrm{mmol}) .{ }^{1} \mathrm{H} \mathrm{NMR}\left(300 \mathrm{MHz}, \mathrm{CDCl}_{3}\right): \delta$ 1.75-1.95 (overlapping singlets, $\left.6 \mathrm{H}, 2\left[\mathrm{FcCH}_{3}\right]\right), 1.90\left(\mathrm{~m}, 2 \mathrm{H},-\mathrm{CH}_{2}-\right), 2.4\left(\mathrm{~m}, 2 \mathrm{H}, \mathrm{Fc}-\mathrm{CH}_{2}-\right), 3.4\left(\mathrm{td}, 2 \mathrm{H},-\mathrm{CH}_{2}-\mathrm{Br}\right)$, 3.50-3.70 (m, 5H, Fc-H).

Linear polyethyleneimine (LPEI) was prepared as previously published. ${ }^{40}$ LPEI $(0.06 \mathrm{~g}$, $1.5 \mathrm{mmol})$ was dissolved in a mixture of acetonitrile and methanol (10:1, $10 \mathrm{~mL})$ and heated to reflux solvent. 3-(bromopropyl)dimethylferrocene $(0.10 \mathrm{~g}, 0.3 \mathrm{mmol})$ in methanol $(1 \mathrm{~mL})$ was added to the refluxing LPEI solution. The reaction mixture was stirred for 24 hours at reflux temperature. The solvent was removed under reduced pressure and the product was extracted using diethyl ether to remove any excess starting material. The final polymer was determined to 
be $\sim 20 \%$ substituted by ${ }^{1} \mathrm{H}$ NMR analysis, which was consistent with the previously reported polymer. $^{40}$

Anthracene-modified multi-walled carbon nanotubes (AcMWCNTs) and TBABmodified Nafion ${ }^{\circledR}$ (TBAB-Nafion ${ }^{\circledR}$ ) were prepared as previously reported. ${ }^{37}$ Toray ${ }^{\circledR}$ carbon paper was cut and wax-coated to give a final exposed geometric surface area of $1 \mathrm{~cm}^{2}$.

\subsection{Instrumentation}

Electrochemical analyses were conducted using a Digi-IVY DY2100-2300 mini-potentiostat (Digi-IVY Inc., USA). Bioanode and biocathode characterization was performed using a threeelectrode configuration, where a Pt mesh was used at the counter electrode and a saturated calomel electrode (SCE) was used as the reference electrode. Enzyme fuel cell (EFC) performances were evaluated by performing linear sweep voltammetry (LSV) from the OCV of the EFC to $5 \mathrm{mV}$, at a scan rate of $1 \mathrm{mV} \mathrm{s}^{-1}$. All current and power densities are reported as a function of the geometric surface area of the respective anodic and cathodic electrodes. Enzymatic activity assays were performed using a Thermo Scientific ${ }^{\odot}$ Evolution 260 Bio UVVisible Spectrophotometer. All experiments were performed in triplicate and errors are reported as standard deviation.

\subsection{Bioelectrode Modification}

BOx/AcMWCNTs biocathodes were prepared as previously reported. ${ }^{21,}{ }^{25} \mathrm{BOx}$ (1.5 mg) was initially suspended in $75 \mu \mathrm{L}$ of citrate/phosphate buffer (pH 7.4, $200 \mathrm{mM}$ ) and then added to 7.5 mg of AcMWCNTs. In total, this mixture was vortexed for 4 minutes and sonicated for 1 minute, in 4 vortex/sonication steps. Lastly, $25 \mu \mathrm{L}$ of TBAB-Nafion ${ }^{\circledR}$ was added to the mixture followed by vortex mixing for 1 minute and sonication for 15 seconds. This mixture was divided between 3 electrodes and applied with a small brush, yielding approximately $33 \mu \mathrm{L}$ per electrode. The resulting electrodes were gently dried under a positive airflow.

FAD-GDH/FcMe ${ }_{2}-\mathrm{C}_{3}$-LPEI bioanodes were prepared by mixing $\mathrm{FcMe}_{2}-\mathrm{C}_{3}$-LPEI $(14 \mu \mathrm{L}$, $\left.10 \mathrm{mg} \mathrm{mL} \mathrm{m}^{-1}\right)$, FAD-GDH $\left(6 \mu \mathrm{L}, 30 \mathrm{mg} \mathrm{mL}^{-1}\right)$ and EGDGE $(0.75 \mu \mathrm{L}, 10 \% \mathrm{v} / \mathrm{v})$. From this mixture, $3 \mu \mathrm{L}$ was applied to each GC electrode surface (which was previously polished with successive alumina slurry grades) and left to dry overnight, at room temperature. Control bioanodes and biocathodes were fabricated by following identical procedures for bioanode and biocathode fabrication, although the respective enzyme was replaced with BSA (at the same concentration by mass).

\section{Results and Discussion}

\subsection{Bioanode Characterization}

Initially, the FAD-GDH bioanodes were characterized in citrate/phosphate buffer at $\mathrm{pH} 7.4$ to confirm mediated bioelectrocatalysis by the $\mathrm{FcMe}_{2}-\mathrm{C}_{3}$-LPEI redox hydrogel and evaluate their suitability to physiological conditions. Figure 1A presents cyclic voltammograms of the FADGDH bioanodes in the absence and presence of glucose $(100 \mathrm{mM})$, and reports the steady-state 
catalytic current response to varying concentrations of glucose (under hydrodynamic conditions, Figure 1B).

\section{[Inset Figure 1 here]}

In citrate/phosphate buffer a pair of quasi-reversible peaks are observed with an $E_{1 / 2}$ of approximately $+200 \mathrm{mV}$ ( $v s$. SCE) and an approximate peak separation of $40 \mathrm{mV}$. Following the addition of glucose (final concentration of $100 \mathrm{mM}$ ) an oxidative catalytic current is observed with an approximate onset potential of $+50 \mathrm{mV}$ ( $v s$. SCE), which is explained by the mediated bioelectrocatalytic oxidation of glucose by FAD-GDH via $\mathrm{FcMe}_{2}$ (immobilized onto LPEI). Control experiments using BSA as a catalytically-inactive protein (in the place of FAD-GDH) confirmed that the catalytic current observed is attributed to FAD-GDH (data not shown).

Steady-state evaluation (Figure 1) of the FAD-GDH bioanodes was performed with increasing concentrations of glucose, where an oxidative potential of $50 \mathrm{mV}$ greater than the oxidative peak potential $\left(E_{\mathrm{ox}}\right)$ was applied $(+270 \mathrm{mV} v s$. SCE). The results were analyzed by nonlinear regression to the Michaelis-Menten model, yielding an apparent Michaelis-Menten constant $\left(K_{m}{ }^{a p p}\right)$ of $21.5 \pm 2.4 \mathrm{mM}$ glucose and a maximum velocity $\left(V_{\max }\right)$ of $492.5 \pm 15.6 \mu \mathrm{A}$ $\mathrm{cm}^{-2}$ (fit shown on Figure 1B).

Following successful mediated bioelectrocatalysis at the FAD-GDH bioanode, the bioanodes were evaluated in human serum at $21^{\circ} \mathrm{C}$ and $37^{\circ} \mathrm{C}$ (Figure 2A and 2B), to investigate their suitability within an implantable scenario. To confirm the mediated bioelectrocatalytic oxidation of glucose (in human serum) by FAD-GDH, BSA control experiments were performed in the place of FAD-GDH. BSA control experiments also confirm that no significant interference is observed between any components of human serum and the $\mathrm{FcMe}_{2}-\mathrm{C}_{3}$ - $\mathrm{LPEI}$ bioanode architecture, under these conditions.

\section{[Insert Figure 2 here]}

At $21^{\circ} \mathrm{C}$, a small oxidative catalytic wave is observed when catalytically-inactive BSA is replaced with FAD-GDH, which is attributed to the mediated bioelectrocatalysis of glucose by the FAD-GDH bioanode. The oxidative currents observed for the FAD-GDH bioanode increase under hydrodynamic conditions, which is explained by an increase in substrate/product diffusion to/from the bioanode. Following the addition of $95 \mathrm{mM}$ glucose to the human serum (to yield an approximate final glucose concentration of $100 \mathrm{mM}$, where $5 \mathrm{mM}$ glucose is commonly considered to be an average physiological glucose concentration ${ }^{2}$ ), an increase in the oxidative wave is observed, which reflects the sub-saturating concentrations of glucose present in human serum.

At an increased temperature of $37^{\circ} \mathrm{C}$, the catalytic-currents under quiescent/hydrostatic conditions as well as under hydrodynamic conditions are increased; the oxidative catalytic currents are further increased with an addition of $95 \mathrm{mM}$ glucose. These increases in relative oxidative catalytic currents are explained by the increase in temperature, where the optimal 
temperature is specified by the manufacturer to be greater than $50^{\circ} \mathrm{C}$ (Sekisui Diagnostics' data sheet for GLDE-70-1192).

\subsection{Biocathode Characterization}

The direct bioelectrocatalytic reduction of oxygen by the BOx/AcMWCNTs biocathodes was first evaluated (Figure 3A and 3B) in citrate/phosphate buffer $(0.2 \mathrm{M})$, at physiological $\mathrm{pH}(\mathrm{pH}$ 7.4) and at $21^{\circ} \mathrm{C}$ and $37^{\circ} \mathrm{C}$.

\section{[Insert Figure 3 here]}

Cyclic voltammetry of the BOx/AcMWCNTs biocathodes under aerobic conditions (with and without additional air/oxygen purging) demonstrate the direct bioelectrocatalytic reduction of oxygen at near-neutral $\mathrm{pH}(\mathrm{pH}$ 7.4). Although BOx can be inhibited by urate, this characterisation confirms the ability for these BOx-based biocathodes to efficiently operate in human serum. ${ }^{41,42}$ The onset potential for oxygen reduction is observed at approximately +500 $\mathrm{mV} v$ s. SCE. Under quiescent conditions with no artificial air purging, a reductive catalytic wave is observed for oxygen reduction at the biocathode, although the catalytic wave exhibits characteristics commonly observed for bioelectrodes that are mass transport limited. Evaluation of the BOx biocathodes under hydrodynamic conditions (with no additional air or oxygen purging) appears to improve the apparent mass transport limitation, where remaining limitation can be attributed to dissolved oxygen concentrations and sub-optimal enzymatic bioelectrocatalysis at $\mathrm{pH}$ 7.4. Further, the introduction of oxygen purging throughout the experiment revealed an increase in the current densities of the catalytic wave, due to a relative increase in dissolved oxygen concentration. This is expected, since dissolved oxygen concentrations and concomitant cathodic limitation is usually the limiting factor of EFCs. Evaluation of the $\mathrm{BOx}$ cathodes at $21^{\circ} \mathrm{C}$ and $37^{\circ} \mathrm{C}$ revealed improved performance at $21^{\circ} \mathrm{C}$. Although the catalytic activity of BOx increases with increased temperature, the solubility of dissolved oxygen at $37^{\circ} \mathrm{C}$ is lower and thus, the overall direct bioelectrocatalytic wave is lowered in magnitude. Cyclic voltammetry was used to evaluate the suitability of the BOx biocathodes to operate within an EFC operating in human serum (Figure 4).

\section{[Insert Figure 4 here]}

A reductive catalytic wave was observed for the BOx/AcMWCNTs biocathodes in human serum at $21^{\circ} \mathrm{C}$ and $37^{\circ} \mathrm{C}$. BSA/AcMWCNTs control biocathodes confirmed that bioelectrocatalysis was due to the presence of BOx, with no significant reductive wave observed in the absence of BOx. In comparison to oxygen reduction by the BOx/AcMWCNTs biocathodes operating in buffer ( $\mathrm{pH}$ 7.4), an approximate 3-fold decrease in the maximum direct bioelectrocatalytic current was observed when operating in human serum. It is hypothesized that this decrease in catalytic current is due to inhibition of the BOx by human serum components. 
Although previously reported work has demonstrated minimal interference or inhibition by $\mathrm{Cl}^{-}$, some inhibition is still expected. ${ }^{25}$ Nevertheless, the presence of the reductive catalytic wave still demonstrates the use of BOx/AcMWCNTs biocathodes within EFCs operating in human serum.

Interestingly, an oxidative wave is observed (with an approximate onset potential of +425 $\mathrm{mV} v s$. SCE) when operating in human serum at $37^{\circ} \mathrm{C}$. Since this oxidative wave is also present at the BSA/AcMWCNTs control biocathodes, it is hypothesized that this is due to the oxidation of human serum components (such as ascorbic acid) at the Toray ${ }^{\circledR}$ electrode (carbon paper). Since this oxidative wave does not seriously encroach onto the potential window for bioelectrocatalytic oxygen reduction, no significant competition between the oxidative and reductive catalytic wave is expected.

\subsection{Enzymatic Fuel Cell (EFC) Characterization}

The FAD-GDH/FcMe ${ }_{2}-\mathrm{C}_{3}$-LPEI bioanodes and BOx/AcMWCNTs biocathodes were combined as complete EFCs. The resulting EFCs were compared and contrasted in buffer $(0.2 \mathrm{M}, \mathrm{pH} 7.4$ citrate/phosphate) and in human serum, at $21^{\circ} \mathrm{C}$ and $37^{\circ} \mathrm{C}$ (Figure 5A and 5B). The EFCs were evaluated under hydrodynamic (stirred) conditions to further simulate implantation within a living host's bloodstream or physiological fluid. FAD-GDH bioanodes were prepared on $3 \mathrm{~mm}$ GC electrodes and BOx biocathodes were prepared on Toray ${ }^{\circledR}$ paper electrodes $\left(1 \mathrm{~cm}^{2}\right)$, where the bioanode (GC) was the limiting EFC bioelectrode.

\section{[Insert Figure 5 here]}

Table 1 reports the OCVs of the complete EFCs operating in both citrate/phosphate buffer and human serum. A small decrease in OCV was observed between the EFCs operating in buffer and in human serum. Activation losses such as these could be due to mild enzymatic deactivation by compounds found within serum (such as urate or halide ions). It is also possible that other redox-active species present within human serum may be introducing cross-potentials at the bioanode and/or biocathode. Linear polarization was performed from the OCV to $5 \mathrm{mV}$, at $1 \mathrm{mV} \mathrm{s}^{-1}$. Slow polarization has been demonstrated as an efficient electrochemical method for characterizing EFCs. ${ }^{43}$

\section{[Insert Table 1 here]}

Although the OCVs of the EFCs operating in buffer and human serum were comparable, a small decrease is observed for the EFCs when analyzed in human serum. This can be explained by activation losses, which are reflected in the onset of bioelectrocatalysis at both the bioanode and biocathode due to other components of serum, which may interfere at either electrode. Also, as demonstrated in Figure 4, a small competitive oxidation wave is observed at the BSA/AcMWCNTs biocathode. This also suggests that any overlap between the onset of oxygen 
reduction and this competitive oxidation wave could result in a compromise of the OCV of the EFC.

Interestingly, the introduction of $95 \mathrm{mM}$ additional glucose into human serum when operating at $37^{\circ} \mathrm{C}$ results in improved overall performance (in terms of maximum current densities) of the EFCs. Although the maximum current densities increase, there is no statistically-significant increase in the maximum power density of the EFCs. It is hypothesized that the increase in the maximum current densities could be a function of enzymatic-activation (increased enzymatic activity and thus, increased bioelectrocatalysis) from another component of human serum, although further investigations are needed to determine the reason behind increased current densities. These increases in current densities are likely to be a function of increased enzymatic activities at increased temperature (since the optimal enzymatic activities of these enzymes are found near $37^{\circ} \mathrm{C}$ ). Since the maximum current densities are achieved at relatively-lower EFC voltages (nearer to the short-circuit potential), the insignificant change in maximum power densities suggest that other factors, such as mass transport limitation, may also be a significant limiting factor at the bioanode/biocathode. It is important to note that small power densities $\left(<10 \mu \mathrm{W} \mathrm{cm}{ }^{-2}\right)$ are observed for EFCs operating in buffer in the absence of glucose. These power densities are a function of the electrochemical technique used to characterize the EFCs (linear sweep voltammetry at a scan rate of $1 \mathrm{mV} \mathrm{s}^{-1}$ ) whereby the oxidation of reduced bioanode mediator is observed. Slower scan rates can be used to minimize these contributions, although a scan rate of $1 \mathrm{mV} \mathrm{s}^{-1}$ was used as it also allows rapid EFC characterization and comparison.

To account for and eliminate any non-enzymatic contributions at either the bioanode or biocathode, a series of control EFCs were evaluated in human serum. Combinations of BSA control bioanodes or biocathodes were coupled with enzymatic bioanodes or biocathodes and compared against complete EFCs (Figure 6).

\section{[Insert Figure 6 here]}

Control EFCs were evaluated by polarization at a scan rate of $1 \mathrm{mV} \mathrm{s}^{-1}$ from the OCVs determined for the complete/fully-enzymatic EFCs. In the absence of enzyme biocatalysts at either the bioanode or biocathode, a marked decrease in EFC performance is observed, which confirms the need for the enzyme biocatalysts at both the bioanode and the biocathode in order to achieve such current densities and power densities at these OCVs. When BSA control bioanodes (still containing the DMFc-C ${ }_{3}$-LPEI redox hydrogel) are coupled with BOx/AcMWCNTs biocathodes, a small pseudo-enzymatic polarization is observed. Since the overall EFC performance is a function of the combined performances at both the bioanode and biocathode, it is hypothesized that this apparent peak is due to a combination of the oxidation of any reduced $\mathrm{DMFc}$ at the electrode along with small contributions from charging currents (due to polarization), which are amplified (in comparison to the FAD-GDH/BSA control EFC) since oxygen reduction at the BOx biocathode still occurs. To further support this hypothesis, when 
FAD-GDH bioanodes (containing the $\mathrm{DMFc}_{3} \mathrm{C}_{3}$-LPEI redox hydrogel with substrate present) are coupled with BSA control biocathodes this apparent peak is not observed, since there is negligible cathodic activity in the absence of BOx.

Lastly, the performance of the EFCs over a 24-hour operational window was investigated; the EFCs were continually discharged (potentiostatic) at $0.2 \mathrm{~V}$, which was the approximate potential at which the maximum power density was recorded (Figure 7A and 7B). This analysis provides information about the stability of the device at near-optimal performance under continuous operation. The recorded power densities were corrected to $t=100$ seconds, to account for initial diffusional equilibration and charging currents.

\section{[Insert Figure 7 here]}

When operating in buffer containing $5 \mathrm{mM}$ glucose, the EFCs produced initial $(t=100$ seconds) power densities of $29.6 \pm 1.0 \mu \mathrm{W} \mathrm{cm}$ and $38.1 \pm 6.1 \mu \mathrm{W} \mathrm{cm}{ }^{-2}$ at $21^{\circ} \mathrm{C}^{-2}$ and $37^{\circ} \mathrm{C}$, respectively. EFCs operating at $37^{\circ} \mathrm{C}$ produced larger initial power densities (as reported in Figure 5 and Table 1) due to increased enzymatic activity at heightened temperature, although decreased stabilities were observed with final recorded power densities of $13.3 \pm 1.0\left(21^{\circ} \mathrm{C}\right)$ and $3.6 \pm 0.9 \mu \mathrm{W} \mathrm{cm}{ }^{-2}\left(37^{\circ} \mathrm{C}\right)$. It is expected that this relatively increased instability of the EFCs operating at $37^{\circ} \mathrm{C}$ is as function of bioelectrode stability over time at this temperature.

To evaluate the performance of the EFCs within an implantable scenario, their performance over time was evaluated in human serum. Initial ( $t=100$ seconds) power densities of $28.9 \pm 8.9 \mu \mathrm{W} \mathrm{cm}$ and $40.3 \pm 2.6 \mu \mathrm{W} \mathrm{cm}{ }^{-2}$ were reported at $21^{\circ} \mathrm{C}$ and $37^{\circ} \mathrm{C}$, respectively. Although the EFCs which were operated at $37^{\circ} \mathrm{C}$ showed higher initial power densities (due to heightened enzymatic activity), the EFCs showed a marked decrease in performance after approximately 13-14 hours of continuous operation. In addition, the serum aliquots became lightened in color and more opaque in appearance. In a similar manner to the EFCs evaluated in buffer, the EFCs at $37^{\circ} \mathrm{C}$ showed decreased stability, with final ( $t=13$ hours) power densities of $9.7 \pm 3.6 \mu \mathrm{W} \mathrm{cm}{ }^{-2}$ (approximately $76 \%$ loss); in contrast the EFCs operated at $21^{\circ} \mathrm{C}$ produced final power densities of $11.6 \pm 4.8 \mu \mathrm{W} \mathrm{cm} \mathrm{cm}^{-2}$ (approximately $60 \%$ loss).

\section{Conclusions}

The performances of glucose/oxygen EFCs utilizing FAD-GDH at the bioanode and BOx at the biocathode were compared and contrasted in buffer and human serum, to evaluate the performances of the resulting devices in an implantable scenario. Bioelectrocatalysis at the bioanodes and biocathodes was evaluated in human serum, with and without additional glucose. Interestingly, the introduction of an additional $95 \mathrm{mM}$ glucose into human serum resulted in increased maximum current densities (in comparison to EFCs evaluated in buffer containing 100 $\mathrm{mM}$ glucose). Comparable maximum current and power densities of EFCs were obtained, operating within either buffer or human serum, further suggesting the suitability of these EFCs within an implantable scenario. 
The stabilities of the EFCs were evaluated in buffer (containing $5 \mathrm{mM}$ glucose) and human serum (at $21^{\circ} \mathrm{C}$ and $37^{\circ} \mathrm{C}$ ) over a continuous 24 -hour operational window, at near-optimal output. These harsh evaluation conditions were used to expose the absolute maximum performance that could be obtained from these EFCs, to allow for further development and improvement. Potentiostatic measurements have been shown to result in lower stabilities versus

galvanostatic measurements. ${ }^{37}$ Although the EFCs operated at $21^{\circ} \mathrm{C}$ in human serum showed a respectable remaining power output of approximately $40 \%$ after 24 hours of continual operation, the EFCs operated at $37^{\circ} \mathrm{C}$ exhibited decreased stability with complete failure repeatedly occurring after approximately 14 hours of operation. Further studies are required to investigate the mode by which the EFCs failed, so that EFCs can be designed to operate stably at $37^{\circ} \mathrm{C}$.

\section{Acknowledgements}

The authors thank the National Science Foundation for funding (CHE-1057597). The authors also thank Amano Enzyme Inc. (Japan) for providing bilirubin oxidase (BOx, BO-3).

\section{References}

1. D. Leech, P. Kavanagh and W. Schuhmann, Enzymatic fuel cells: Recent progress, Electrochim. Acta, 2012, 84, 223-234.

2. M. Shao, M. N. Zafar, M. Falk, R. Ludwig, C. Sygmund, C. K. Peterbauer, D. A. Guschin, D. MacAodha, P. O. Conghaile, D. Leech, M. D. Toscano, S. Shleev, W. Schuhmann and L. Gorton, Optimization of a Membraneless Glucose/Oxygen Enzymatic Fuel Cell Based on a Bioanode with High Coulombic Efficiency and Current Density, ChemPhysChem, 2013, 14, 2260-2269.

3. B. Reuillard, A. Le Goff, C. Agnes, M. Holzinger, A. Zebda, C. Gondran, K. Elouarzaki and S. Cosnier, High power enzymatic biofuel cell based on naphthoquinone-mediated oxidation of glucose by glucose oxidase in a carbon nanotube 3D matrix, Phys. Chem. Chem. Phys., 2013, 15, 4892-4896.

4. D. P. Hickey, F. Giroud, D. W. Schmidtke, D. T. Glatzhofer and S. D. Minteer, Enzyme Cascade for Catalyzing Sucrose Oxidation in a Biofuel Cell, ACS Catal., 2013, 3, 27292737.

5. S. Aquino Neto, E. L. Suda, S. Xu, M. T. Meredith, A. R. De Andrade and S. D. Minteer, Direct electron transfer-based bioanodes for ethanol biofuel cells using PQQ-dependent alcohol and aldehyde dehydrogenases, Electrochim. Acta, 2013, 87, 323-329.

6. S. Xu and S. D. Minteer, Enzymatic Biofuel Cell for Oxidation of Glucose to CO2, ACS Catal., 2012, 2, 91-94.

7. S. D. Minteer, P. Atanassov, H. R. Luckarift and G. R. Johnson, New materials for biological fuel cells, Mater. Today, 2012, 15, 166-173.

8. M. T. Meredith and S. D. Minteer, Biofuel cells: enhanced enzymatic bioelectrocatalysis, Annu. Rev. Anal. Chem., 2012, 5, 157-179.

9. L. Halamkova, J. Halamek, V. Bocharova, A. Szczupak, L. Alfonta and E. Katz, Implanted biofuel cell operating in a living snail, J. Am. Chem. Soc., 2012, 134, 50405043. 
10. M. Rasmussen, R. E. Ritzmann, I. Lee, A. J. Pollack and D. Scherson, An Implantable Biofuel Cell for a Live Insect, J. Am. Chem. Soc., 2012, 134, 1458-1460.

11. A. Szczupak, J. Halamek, L. Halamkova, V. Bocharova, L. Alfonta and E. Katz, Living battery - biofuel cells operating in vivo in clams, Energy Environ. Sci., 2012, 5, 88918895.

12. A. Zebda, S. Cosnier, J. P. Alcaraz, M. Holzinger, A. Le Goff, C. Gondran, F. Boucher, F. Giroud, K. Gorgy, H. Lamraoui and P. Cinquin, Single Glucose Biofuel Cells Implanted in Rats Power Electronic Devices, Sci. Rep., 2013, 3, 1-5.

13. P. Cinquin, C. Gondran, F. Giroud, S. Mazabrard, A. Pellissier, F. Boucher, J. P. Alcaraz, K. Gorgy, F. Lenouvel, S. Mathe, P. Porcu and S. Cosnier, A Glucose BioFuel Cell Implanted in Rats, PLoS One, 2010, 5, 1 - 7.

14. V. Coman, R. Ludwig, W. Harreither, D. Haltrich, L. Gorton, T. Ruzgas and S. Shleev, A Direct Electron Transfer-Based Glucose/Oxygen Biofuel Cell Operating in Human Serum, Fuel Cells, 2010, 10, 9-16.

15. C. Pan, Y. Fang, H. Wu, M. Ahmad, Z. Luo, Q. Li, J. Xie, X. Yan, L. Wu, Z. L. Wang and J. Zhu, Generating Electricity from Biofluid with a Nanowire-Based Biofuel Cell for Self-Powered Nanodevices, Adv. Mater., 2010, 22, 5388-5392.

16. M. Southcott, K. MacVittie, J. Halamek, L. Halamkova, W. D. Jemison, R. Lobel and E. Katz, A pacemaker powered by an implantable biofuel cell operating under conditions mimicking the human blood circulatory system - battery not included, Phys. Chem. Chem. Phys., 2013, 15, 6278-6283.

17. K. MacVittie, J. Halamek, L. Halamkova, M. Southcott, W. D. Jemison, R. Lobel and E. Katz, From "cyborg" lobsters to a pacemaker powered by implantable biofuel cells, Energy Environ. Sci., 2013, 6, 81-86.

18. V. Coman, C. Vaz-Dominguez, R. Ludwig, W. Herreither, D. Haltrich, A. L. De Lacey, T. Ruzgas, L. Gorton and S. Shleev, A membrane-, mediator-, cofactor-less glucose/oxygen biofuel cell, Phys. Chem. Chem. Phys., 2008, 10, 6093-6096.

19. E. Katz, I. Willner and A. B. Kotlyar, A non-compartmentalized glucose vertical bar O-2 biofuel cell by bioengineered electrode surfaces, J. Electroanal. Chem., 1999, 479, 64-68.

20. R. D. Milton, F. Giroud, A. E. Thumser, S. D. Minteer and R. C. T. Slade, Hydrogen peroxide produced by glucose oxidase affects the performance of laccase cathodes in glucose/oxygen fuel cells: FAD-dependent glucose dehydrogenase as a replacement, Phys. Chem. Chem. Phys., 2013, 15, 19371-19379.

21. R. D. Milton, F. Giroud, A. E. Thumser, S. D. Minteer and R. C. T. Slade, Glucose oxidase progressively lowers bilirubin oxidase bioelectrocatalytic cathode performance in single-compartment glucose/oxygen biological fuel cells, Electrochim. Acta, 2014, 140, 59-64.

22. M. N. Zafar, N. Beden, D. Leech, C. Sygmund, R. Ludwig and L. Gorton, Characterization of different FAD-dependent glucose dehydrogenases for possible use in glucose-based biosensors and biofuel cells, Anal. Bioanal. Chem., 2012, 402, 2069-2077.

23. O. Yehezkeli, R. Tel-Vered, S. Reichlin and I. Willner, Nano-engineered FlavinDependent Glucose Dehydrogenase/Gold Nanoparticle-Modified Electrodes for Glucose Sensing and Biofuel Cell Applications, ACS Nano, 2011, 5, 2385-2391.

24. S. Tsujimura, S. Kojima, K. Kano, T. Ikeda, M. Sato, H. Sanada and H. Omura, Novel FAD-dependent glucose dehydrogenase for a dioxygen-insensitive glucose biosensor, Biosci. Biotechnol. Biochem., 2006, 70, 654-659. 
25. R. D. Milton, F. Giroud, A. E. Thumser, S. D. Minteer and R. C. T. Slade, Bilirubin oxidase bioelectrocatalytic cathodes: the impact of hydrogen peroxide, Chem. Commun., 2014, 50, 94-96.

26. I. Osadebe and D. Leech, Effect of Multi-Walled Carbon Nanotubes on Glucose Oxidation by Glucose Oxidase or a Flavin-Dependent Glucose Dehydrogenase in RedoxPolymer-Mediated Enzymatic Fuel Cell Anodes, ChemElectroChem, 2014, n/a-n/a.

27. U. Salaj-Kosla, S. Poeller, Y. Beyl, M. D. Scanlon, S. Beloshapkin, S. Shleev, W. Schuhmann and E. Magner, Direct electron transfer of bilirubin oxidase (Myrothecium verrucaria) at an unmodified nanoporous gold biocathode, Electrochem. Commun., 2012, 16, 92-95.

28. U. Salaj-Kosla, S. Poeller, W. Schuhmann, S. Shleev and E. Magner, Direct electron transfer of Trametes hirsuta laccase adsorbed at unmodified nanoporous gold electrodes, Bioelectrochemistry, 2013, 91, 15-20.

29. X. Wang, M. Falk, R. Ortiz, H. Matsumura, J. Bobacka, R. Ludwig, M. Bergelin, L. Gorton and S. Shleev, Mediatorless sugar/oxygen enzymatic fuel cells based on gold nanoparticle-modified electrodes, Biosens. Bioelectron., 2012, 31, 219-225.

30. J. Hirose, K. Inoue, H. Sakuragi, M. Kikkawa, M. Minakami, T. Morikawa, H. Iwamoto and K. Hiromi, Anions binding to bilirubin oxidase from Trachyderma tsunodae K-2593, Inorg. Chim. Acta, 1998, 273, 204-212.

31. E. I. Solomon, U. M. Sundaram and T. E. Machonkin, Multicopper oxidases and oxygenases, Chem. Rev., 1996, 96, 2563-2605.

32. L. dos Santos, V. Climent, C. F. Blanford and F. A. Armstrong, Mechanistic studies of the 'blue' $\mathrm{Cu}$ enzyme, bilirubin oxidase, as a highly efficient electrocatalyst for the oxygen reduction reaction, Phys. Chem. Chem. Phys., 2010, 12, 13962-13974.

33. N. Mano and L. Edembe, Bilirubin oxidases in bioelectrochemistry: Features and recent findings, Biosens. Bioelectron., 2013, 50, 478-485.

34. N. Mano, Features and applications of bilirubin oxidases, Appl. Microbiol. Biotechnol., 2012, 96, 301-307.

35. C. W. Lee, H. B. Gray, F. C. Anson and B. G. Malmstrom, Catalysis of the reduction of dioxygen at graphite-electrodes coated with fungal laccase-A, J. Electroanal. Chem., 1984, 172, 289-300.

36. C. F. Blanford, C. E. Foster, R. S. Heath and F. A. Armstrong, Efficient electrocatalytic oxygen reduction by the 'blue' copper oxidase, laccase, directly attached to chemically modified carbons, Faraday Discuss., 2008, 140, 319-335.

37. M. T. Meredith, M. Minson, D. Hickey, K. Artyushkova, D. T. Glatzhofer and S. D. Minteer, Anthracene-Modified Multi-Walled Carbon Nanotubes as Direct Electron Transfer Scaffolds for Enzymatic Oxygen Reduction, ACS Catal., 2011, 1, 1683-1690.

38. C. F. Blanford, R. S. Heath and F. A. Armstrong, A stable electrode for high-potential, electrocatalytic $\mathrm{O}(2)$ reduction based on rational attachment of a blue copper oxidase to a graphite surface, Chem. Commun., 2007, 1710-1712.

39. A. E. G. Cass, G. Davis, G. D. Francis, H. A. O. Hill, W. J. Aston, I. J. Higgins, E. V. Plotkin, L. D. L. Scott and A. P. F. Turner, Ferrocene-mediated enzyme electrode for amperometric determination of glucose, Anal. Chem., 1984, 56, 667-671.

40. M. T. Meredith, D. Y. Kao, D. Hickey, D. W. Schmidtke and D. T. Glatzhofer, High Current Density Ferrocene-Modified Linear Poly(ethylenimine) Bioanodes and Their Use in Biofuel Cells, J. Electrochem. Soc., 2011, 158, B166-B174. 
41. C. Kang, H. Shin, Y. Zhang and A. Heller, Deactivation of bilirubin oxidase by a product of the reaction of urate and O2, Bioelectrochemistry, 2004, 65, 83-88.

42. C. Kang, H. Shin and A. Heller, On the stability of the "wired" bilirubin oxidase oxygen cathode in serum, Bioelectrochemistry, 2006, 68, 22-26.

43. M. J. Moehlenbrock, R. L. Arechederra, K. H. Sjoholm and S. D. Minteer, Analytical Techniques for Characterizing Enzymatic Biofuel Cells, Anal. Chem., 2009, 81, 95389545. 
Figure 1 - (A) Cyclic voltammetry of the FAD-GDH bioanodes in citrate/phosphate buffer $\left(\mathrm{pH} 7.4,0.2 \mathrm{M}, 21^{\circ} \mathrm{C}\right)$ at a scan rate of $10 \mathrm{mV} \mathrm{s}^{-1}$, containing 0 (solid) and $100 \mathrm{mM}$ (dashed) glucose. (B) Steady-state catalytic current response to increasing concentrations of glucose, recorded in hydrodynamic (stirred with a magnetic bar at constant RPM) citrate/phosphate buffer $\left(0.2 \mathrm{M}\right.$. pH $\left.7.4,21^{\circ} \mathrm{C}\right)$, with an applied potential of $+270 \mathrm{mV}$ ( $v s$. SCE). Inset: amperometric traces of the FAD-GDH bioanodes. All electrodes were evaluated in triplicate, with cyclic voltammograms reported as averages with error bars reported as standard deviation.

Figure 2 - (A) Cyclic voltammetry of a (a) BSA control bioanode and (b-d) FAD-GDH bioanodes in human serum $\left(21^{\circ} \mathrm{C}\right)$ at a scan rate of $10 \mathrm{mV} \mathrm{s}^{-1}$, containing no additional (a-c) and $95 \mathrm{mM}$ additional glucose. Bioanodes were evaluated in $(a+b)$ hydrostatic and $(c+d)$ hydrodynamic (stirred) conditions. (B) Cyclic voltammetry of a (a) BSA control bioanode and (b-d) FAD-GDH bioanodes in human serum $\left(37^{\circ} \mathrm{C}\right)$ at a scan rate of $10 \mathrm{mV} \mathrm{s}^{-1}$, containing no $(\mathrm{a}-\mathrm{c})$ and $95 \mathrm{mM}$ additional glucose. Bioanodes were evaluated in $(\mathrm{a}+\mathrm{b})$ hydrostatic and $(\mathrm{c}+\mathrm{d})$ hydrodynamic (stirred) conditions.

Figure 3 - (A) Cyclic voltammetry of BOx/AcMWCNTs biocathodes in citrate/phosphate buffer $(0.2 \mathrm{M}, \mathrm{pH} 7.4$, $21^{\circ} \mathrm{C}$ ) at a scan rate of $1 \mathrm{mV} \mathrm{s}^{-1}$, under nitrogen (a, dashed), air (b, quiescent and hydrostatic), air (c, quiescent but hydrodynamic (stirred)) and continuous oxygen purging (d). (B) Cyclic voltammetry of BOx/AcMWCNTs biocathodes in citrate/phosphate buffer $(0.2 \mathrm{M}, \mathrm{pH} 7.4)$ at a scan rate of $1 \mathrm{mV} \mathrm{s}^{-1}$, operating under quiescent yet hydrodynamic (stirred) conditions at $21^{\circ} \mathrm{C}$ (solid) and $37^{\circ} \mathrm{C}$ (dashed). The dotted line represents a BOx/AcMWCNTs biocathode in the above conditions, although under nitrogen purging and at $21^{\circ} \mathrm{C}$. Error bars report standard deviation for 3 repeats.

Figure 4 - Cyclic voltammetry of BOx/AcMWCNTs biocathodes (solid) and BSA/AcMWCNTs control biocathodes (dashed and dotted) in human serum at $21^{\circ} \mathrm{C}$ (a, dashed) and $37^{\circ} \mathrm{C}$ (b, dotted), measured hydrodynamically (stirred with no air purging) and at a scan rate of $1 \mathrm{mV} \mathrm{s}^{-1}$. Error bars report standard deviation for 3 repeats.

Figure 5 - (A) Linear polarization curves and resulting power curves of complete FAD-GDH/BOx EFCs operating at $21^{\circ} \mathrm{C}$ (dashed) and $37^{\circ} \mathrm{C}$ (solid) in hydrodynamic (stirred) citrate/phosphate buffer (pH 7.4, 0.2 M), containing (a) 0, (b) 5 and (c) $100 \mathrm{mM}$ glucose. (B) Linear polarization curves and resulting power curves of complete FAD$\mathrm{GDH} / \mathrm{BOx}$ EFCs operating at $21^{\circ} \mathrm{C}$ (dashed) and $37^{\circ} \mathrm{C}$ (solid) in hydrodynamic (stirred) human serum, containing (a) 5 and (b) $100 \mathrm{mM}$ glucose.

Table 1 - Open circuit voltages, maximum current densities and maximum power densities of complete FADGDH/BOx EFCs, operating in hydrodynamic (stirred) citrate/phosphate buffer (pH 7.4, 0.2 M) and human serum.

Figure 6 - Linear polarization curves and resulting power curves of BSA/BOx control EFCs (dashed), FADGDH/BSA control EFCs (dotted) and complete FAD-GDH/BOx EFCs (solid) operating at (A) $21^{\circ} \mathrm{C}$ and (B) $37^{\circ} \mathrm{C}$ in hydrodynamic (stirred) human serum (no additional glucose).

Figure 7 - (A) Continuous potentiostatic discharge $(E=0.2$ V) of FAD-GDH/BOx EFCs operating in citrate/phosphate buffer $(0.2 \mathrm{M}, \mathrm{pH} 7.4)$ containing glucose $(5 \mathrm{mM})$, at (a) $21^{\circ} \mathrm{C}$ and (b) $37^{\circ} \mathrm{C}$. Error bars are reported as SD $(\mathrm{n}=3)$. (B) Continuous potentiostatic discharge $(E=0.2 \mathrm{~V})$ of FAD-GDH/BOx EFCs operating in human serum, at (a) $21^{\circ} \mathrm{C}$ and (b) $37^{\circ} \mathrm{C}$. Error bars are reported as SD $(\mathrm{n}=3)$. Bioanodes were prepared on $\mathrm{GC}$ electrodes ( $3 \mathrm{~mm}$ diameter) and biocathodes were prepared on Toray ${ }^{\circledR}$ electrodes $\left(1 \mathrm{~cm}^{2}\right)$. 


\begin{tabular}{|c|c|c|c|c|}
\hline \multirow[b]{3}{*}{$\begin{array}{c}\text { [Glucose] } \\
\text { / } \mathbf{m M}\end{array}$} & \multicolumn{4}{|c|}{ Open Circuit Voltage } \\
\hline & \multicolumn{2}{|c|}{ Citrate/phosphate buffer (pH 7.4) } & \multicolumn{2}{|c|}{ Human serum } \\
\hline & $21^{\circ} \mathrm{C}$ & $37^{\circ} \mathrm{C}$ & $21^{\circ} \mathrm{C}$ & $37^{\circ} \mathrm{C}$ \\
\hline 5 & $0.60 \pm 0.04 \mathrm{~V}$ & $0.58 \pm 0.03 \mathrm{~V}$ & $0.54 \pm 0.02 \mathrm{~V}$ & $0.56 \pm 0.02 \mathrm{~V}$ \\
\hline \multirow[t]{3}{*}{100} & $0.60 \pm 0.04 \mathrm{~V}$ & $0.58 \pm 0.02 \mathrm{~V}$ & $0.53 \pm 0.01 \mathrm{~V}$ & $0.55 \pm 0.02 \mathrm{~V}$ \\
\hline & \multicolumn{4}{|c|}{ Maximum Current Density / Maximum Power Density } \\
\hline & \multicolumn{2}{|c|}{ Citrate/phosphate buffer (pH 7.4) } & \multicolumn{2}{|c|}{ Human serum } \\
\hline $\begin{array}{c}\text { [Glucose] } \\
\text { / mM }\end{array}$ & $21^{\circ} \mathrm{C}$ & $37^{\circ} \mathrm{C}$ & $21^{\circ} \mathrm{C}$ & $37^{\circ} \mathrm{C}$ \\
\hline 5 & $\begin{array}{c}148.6 \pm 17.5 \mu \mathrm{A} \mathrm{cm}^{-2} \\
35.4 \pm 3.3 \mu \mathrm{W} \mathrm{cm}\end{array}$ & $\begin{array}{l}205.7 \pm 9.4 \mu \mathrm{A} \mathrm{cm}^{-2} \\
44.6 \pm 1.9 \mu \mathrm{W} \mathrm{cm}\end{array}$ & $\begin{array}{l}186.6 \pm 7.1 \mu \mathrm{A} \mathrm{cm}^{-2} \\
39.5 \pm 1.3 \mu \mathrm{W} \mathrm{cm}{ }^{-2}\end{array}$ & $\begin{array}{c}285.7 \pm 31.3 \mu \mathrm{A} \mathrm{cm}^{-2} \\
57.5 \pm 5.4 \mu \mathrm{W} \mathrm{cm}\end{array}$ \\
\hline 100 & $\begin{array}{l}524.1 \pm 82.5 \mu \mathrm{A} \mathrm{cm}^{-2} \\
100.4 \pm 11.8 \mu \mathrm{W} \mathrm{cm}\end{array}$ & $\begin{array}{l}673.3 \pm 24.8 \mu \mathrm{A} \mathrm{cm}^{-2} \\
117.8 \pm 4.7 \mu \mathrm{W} \mathrm{cm}^{-2}\end{array}$ & $\begin{array}{r}462.0 \pm 10.9 \mu \mathrm{A} \mathrm{cm}^{-2} \\
83.1 \pm 1.6 \mu \mathrm{W} \mathrm{cm}^{-2}\end{array}$ & $\begin{array}{l}919.6 \pm 79.7 \mu \mathrm{A} \mathrm{cm}^{-2} \\
125.8 \pm 3.2 \mu \mathrm{W} \mathrm{cm}\end{array}$ \\
\hline
\end{tabular}

Table 1 

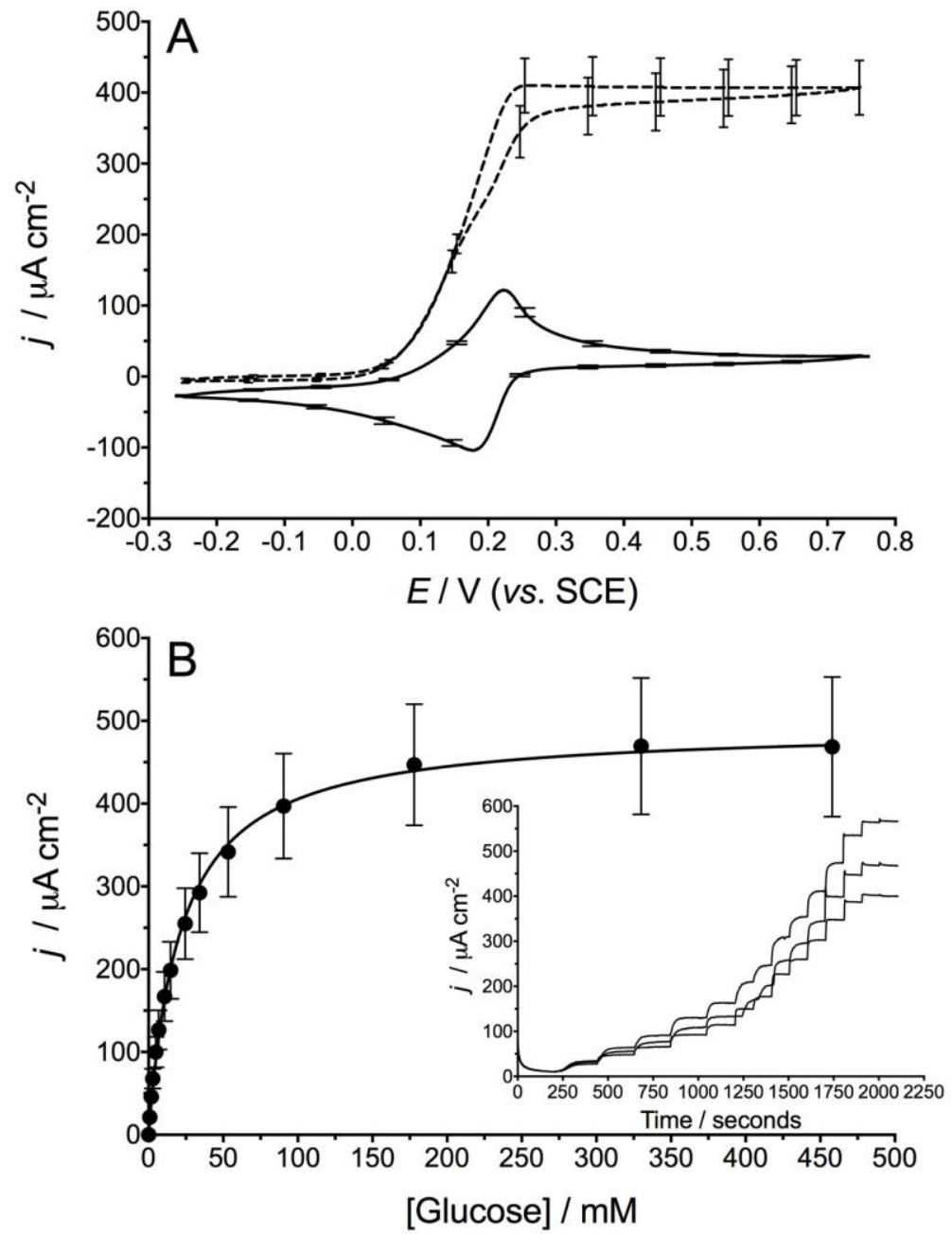

Figure 1 

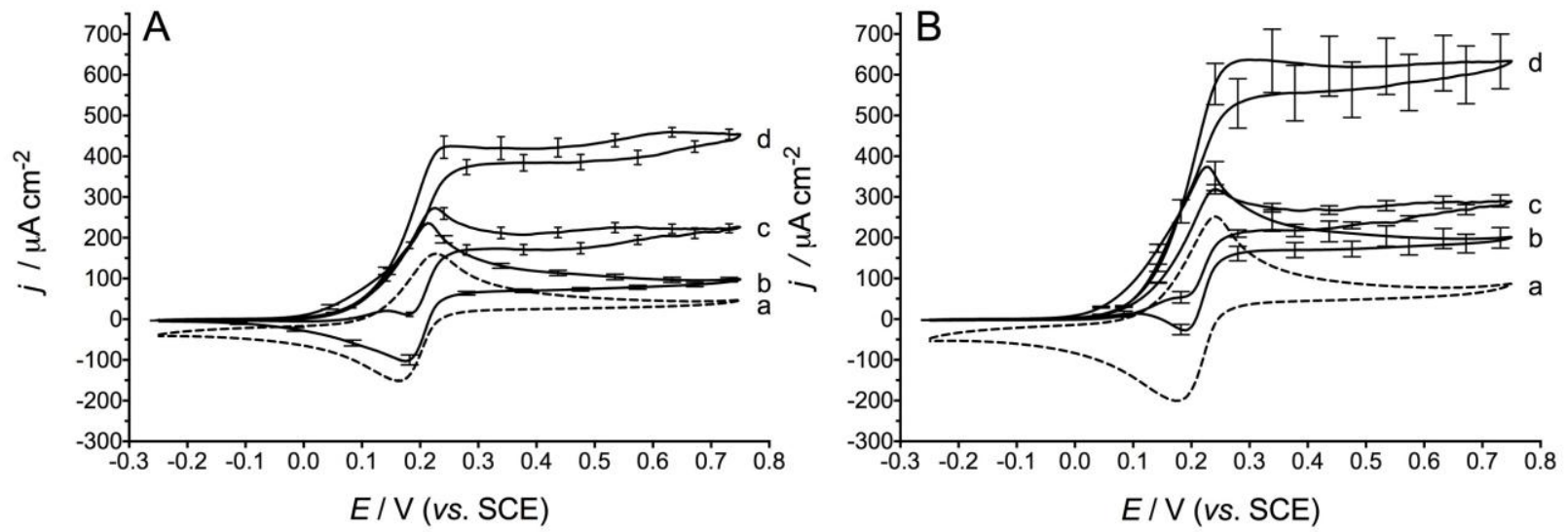

Figure 2 

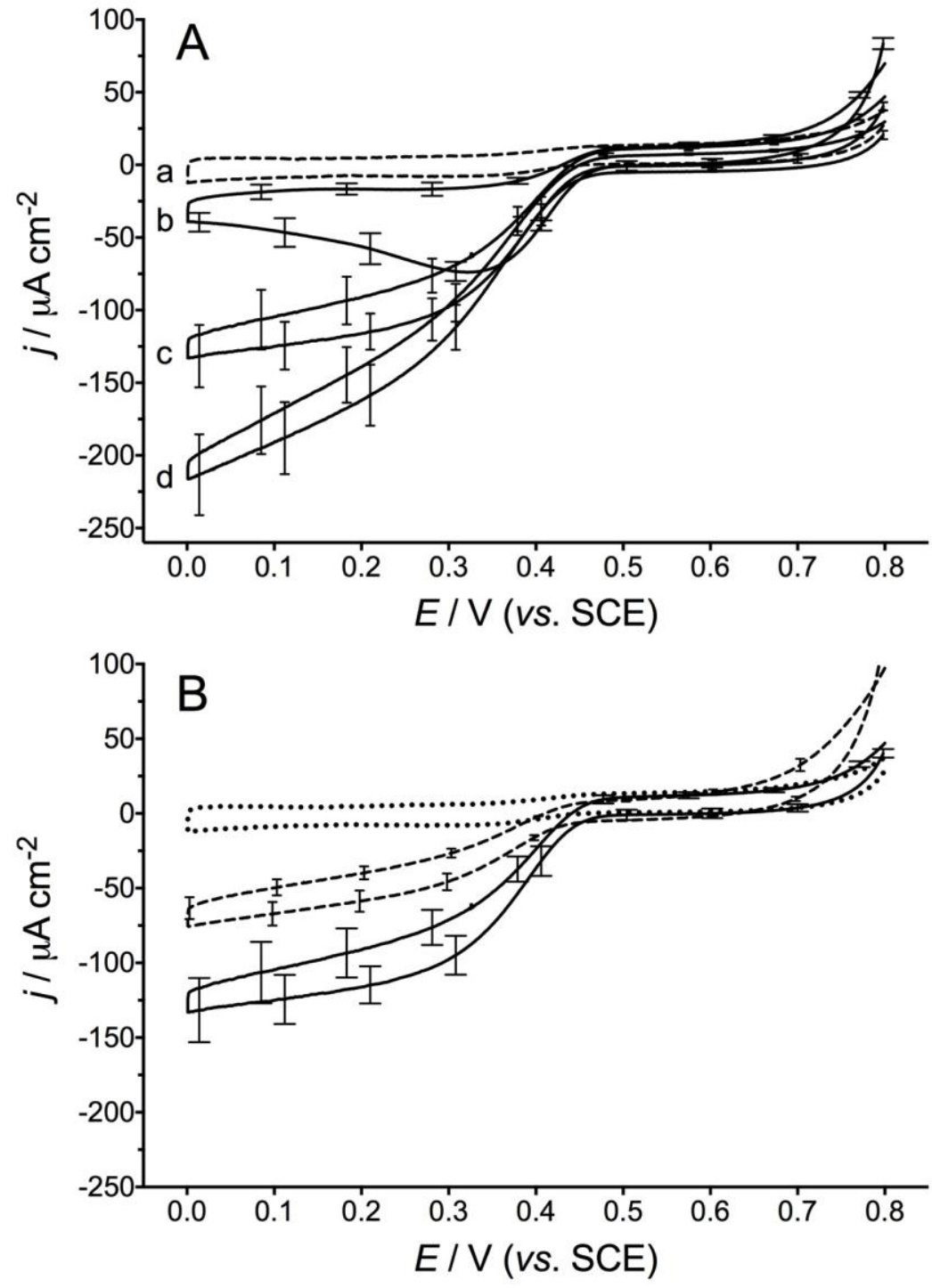

Figure 3 


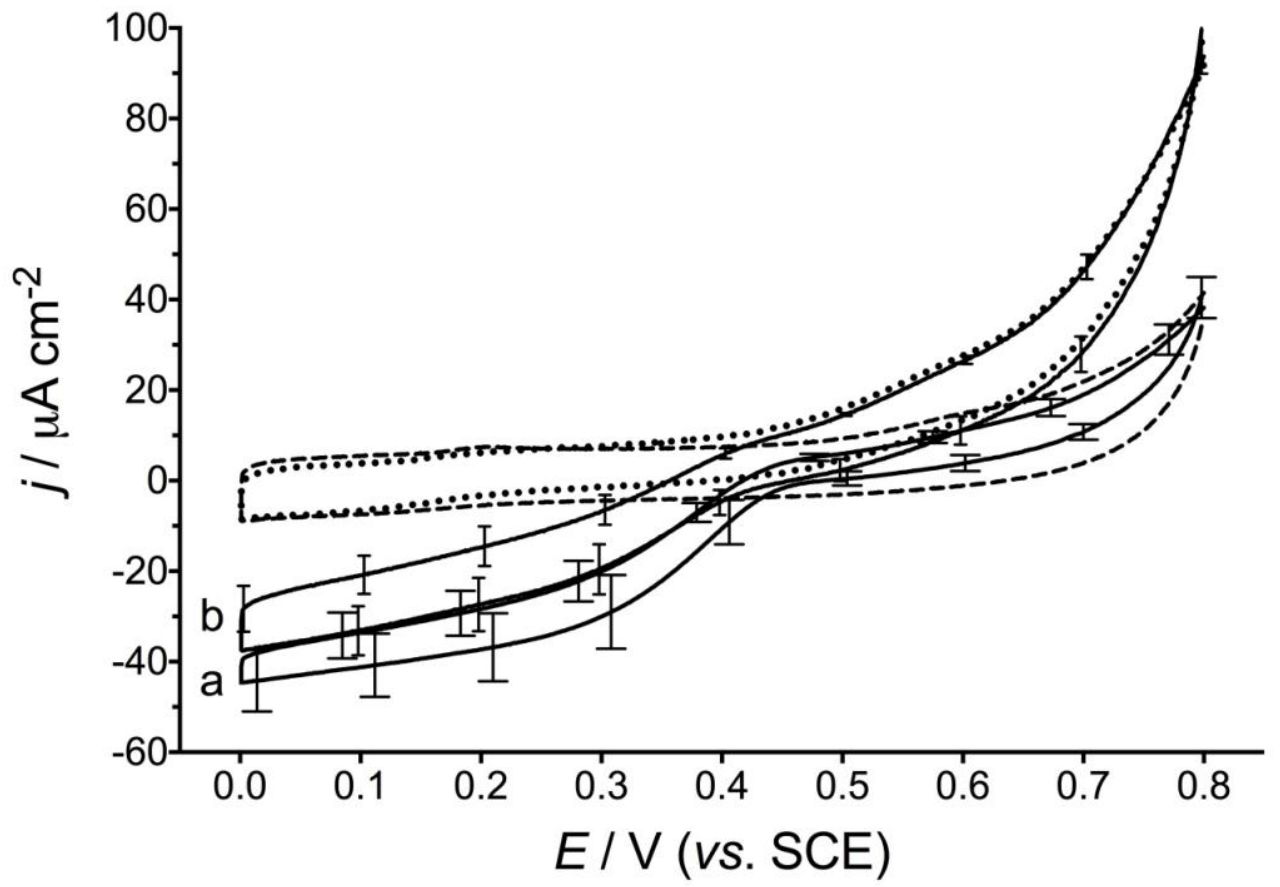

Figure 4 

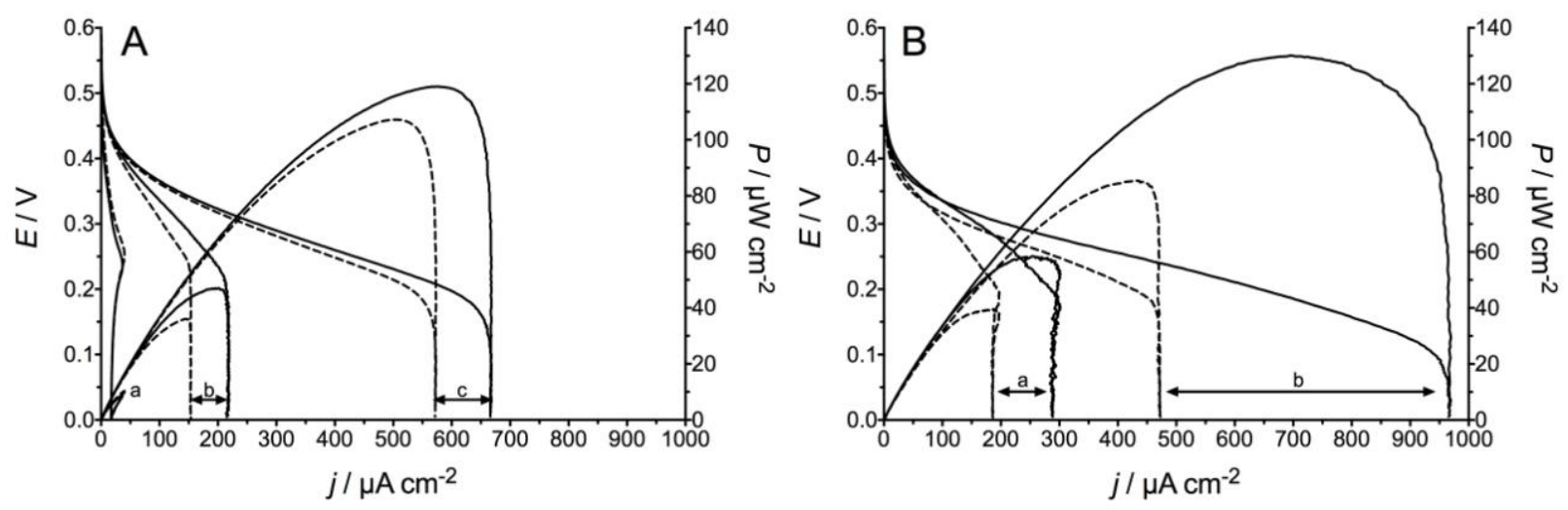

Figure 5 

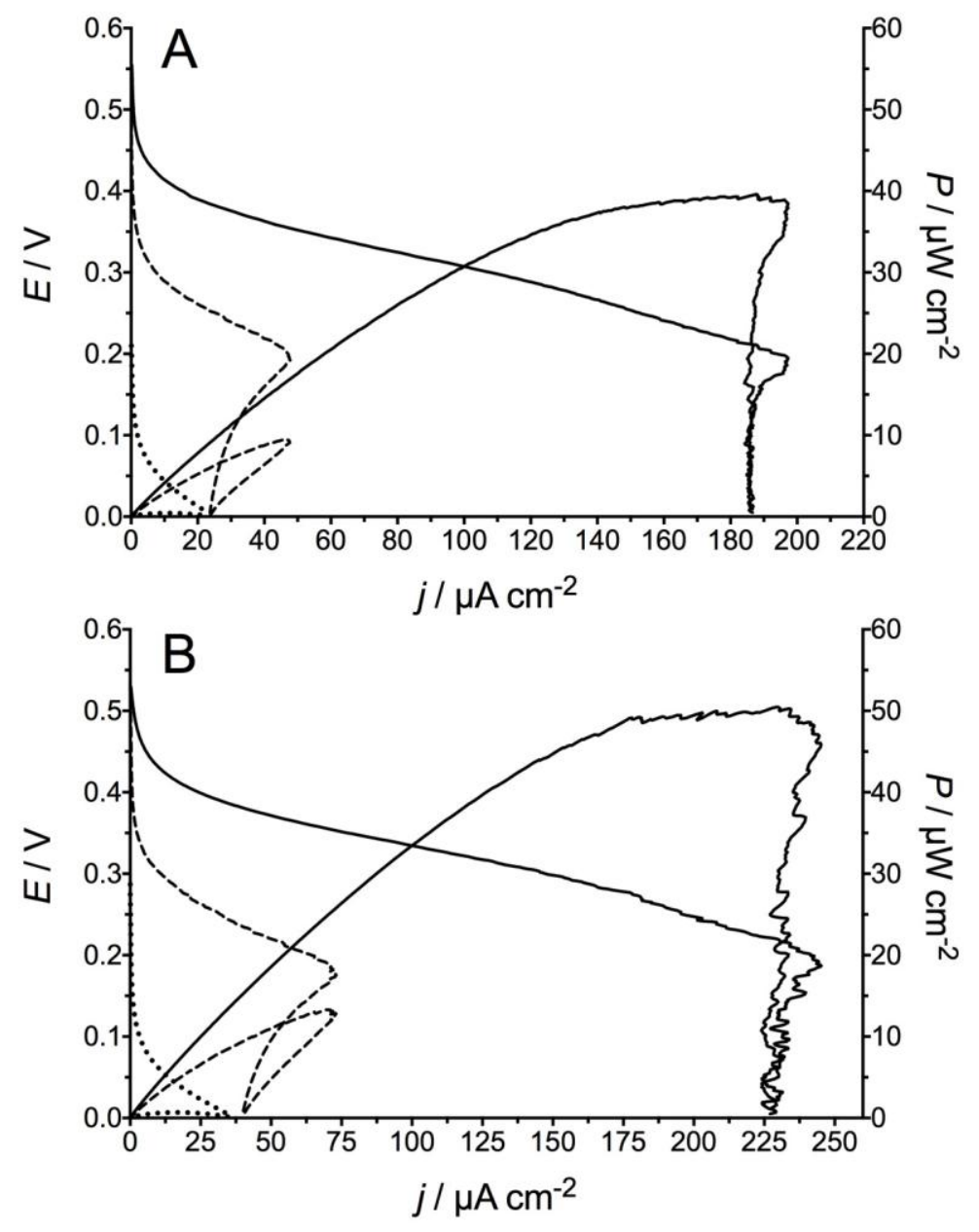

Figure 6 

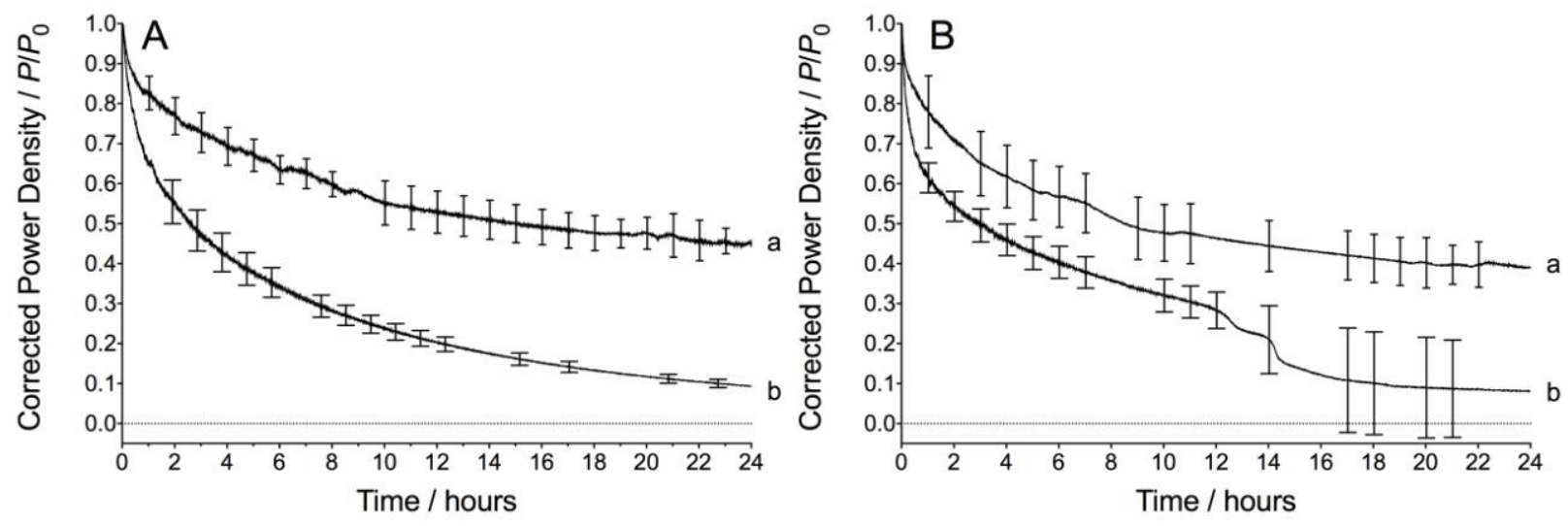

Figure 7 


\section{Biographies}

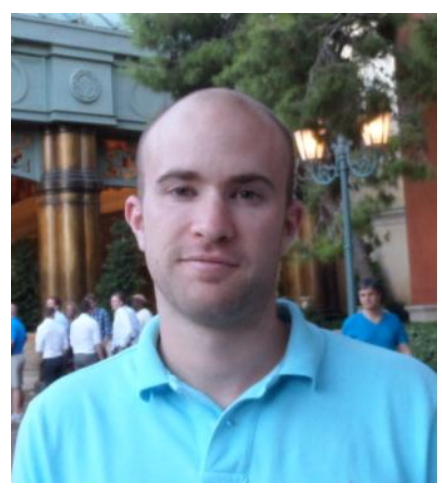

Ross Milton is currently a postdoctoral research fellow within Professor Minteer's research group at the University of Utah (USA). He obtained his BSc (Hons., 2010) in Chemistry and $\mathrm{PhD}$ (2014) at the University of Surrey (UK), researching enzymatic glucose/oxygen fuel cells in Professor Robert Slade's research group. His research interests are alternative glucose-oxidizing enzymes, low potential electron mediator matrices, and quantification of enzyme "cross-talk" and its effect in single-compartment devices.

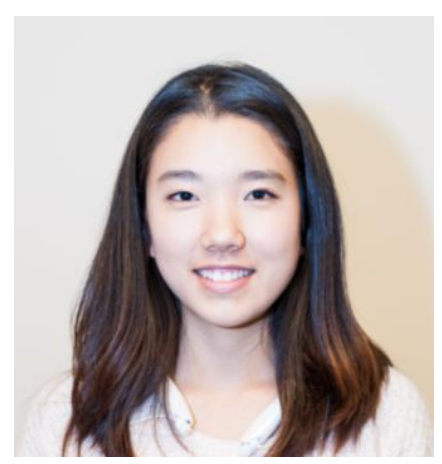

Koun Lim is currently studying chemistry as an undergraduate student at the University of Utah. She is currently investigating the operation of enzymatic fuel cells in physiological environments, in Professor Minteer's research group. Her research interests are improved enzymatic oxygen reduction and alternative enzyme fuel cell configurations. 


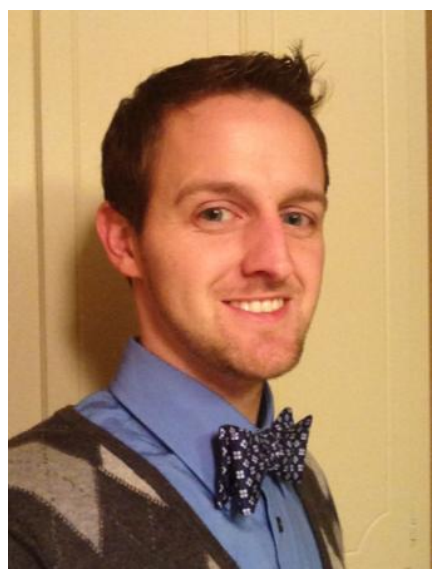

David Hickey received his BSc (2010) and $\mathrm{PhD}$ (2014) in Chemistry at the University of Oklahoma, researching ferrocene-modified redox polymers in biofuel cell materials under Professors Daniel Glatzhofer and David Schmidtke. He is currently a postdoctoral research fellow within Professor Shelley Minteer's research group at the University of Utah. His research interests include the fundamental study of novel catalytic architectures and the development of hybrid catalytic systems.

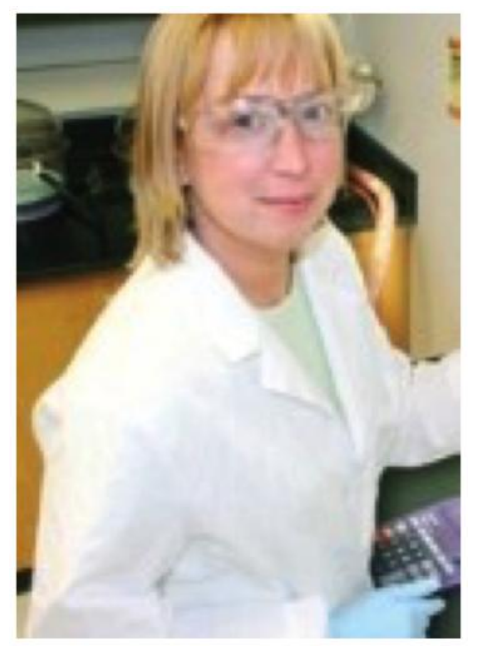

Shelley Minteer received her Bachelor of Science degree at Western Illinois University followed by a $\mathrm{PhD}$ in Analytical Chemistry at University of Iowa. She was a professor of chemistry at Saint Louis University from 2000 to 2011, before taking her current position as a USTAR Professor of Chemistry and Materials Science \& Engineering at University of Utah. Her research interests are in enzyme cascades and metabolons for deep oxidation of biofuels, biofuel cells, bioelectrocatalysis, and biosensors. 